\title{
On-farm evaluation of production potential and economics of Wheat- Jute-T.aman rice-based cropping system
}

\author{
M. M. Kamrozzaman, M. A. H. Khan ${ }^{1 *}$, S. Ahmed, and A. F. M. Ruhul Quddus \\ On-Farm Research Division, Bangladesh Agricultural Research Institute, Faridpur and ${ }^{1}$ On-Farm Research Division, \\ Bangladesh Agricultural Research Institute, Mymensingh, Bangladesh, *Email: helim1367@yahoo.com
}

\begin{abstract}
The study was conducted to determine the yield and economic consequences of two cropping patterns viz. improved cropping pattern (Wheat-Jute-T.aman rice) and farmers, pattern (Wheat-Jute-T.aman rice) through incorporation of modern high yielding varieties and improved management practices for crop production. The experiment was laid out in randomized complete block design with five dispersed replications in farmers' condition in Faridpur during two consecutive years 2011-12 and 2012-13. Two years mean data showed that the improved management practices for the pattern provided significantly higher yield in Wheat, Jute and T.aman rice. The gross return (Tk. 265495/ha) and net return (Tk.123087/ha) of improved pattern were $9 \%$ and $18 \%$ higher, respectively compared to that of farmers' pattern with only $3 \%$ extra cost. The higher benefit cost ratio, land use efficiency, production efficiency and sustainable yield index indicated the superiority of the improved pattern over the farmers' practices.
\end{abstract}

Keywords: Agronomic performance, Land use efficiency, Production potential, Sustainable yield index

\section{Introduction}

There are several cropping patterns involving wheat which are practiced in different Agro Ecological Zones of Bangladesh. Wheat- Jute-T.aman rice is one of the major cropping patterns under irrigated Medium High Land of Faridpur District. About $11 \%$ of the net cropped area under Low Ganges River Floodplain Agro-ecological Zones of Faridpur district (AEZ-12) of Bangladesh are cultivable with wheat based cropping patterns (BBS, 2012). Wheat-Jute-T.aman rice is one of the important and widely accepted pattern in some areas of Bangladesh. On-Farm trials with BARI Gom-26 in Faridpur region performed better than existing varieties. In order to increase production of wheat based cropping patterns BARI Gom-26 may be introduced as an alternative of farmers' one. However, the productivity of this pattern is low due to the use of local varieties and traditional management practices. Farmers' practices wheat-Jute-T.aman rice cropping pattern is greatly influenced by the distribution pattern of annual rainfall. But the nature of distribution and frequency of rainfall (Fig. 1) as recorded at the research site offers opportunity to introduce some modern varieties of wheat and T.aman rice in the cropping pattern. More than $95 \%$ of 9.11 million hectares of net cultivable area is now under cultivation (Alam et al., 1998). There is no alternative to meet the ever increasing demand for food for fast growing population except increasing production from the existing available land in the country. In this context, not only the modern production technology and complementary inputs are essential but also the diversification of crops throughout the country is foremost. The important aspects in this regard are to explore the possibility to fit a new crop without disturbing the existing ones. Overall productivity as well as profitability of the farmers could be increased considerably by introducing modern varieties and improved management practices. A number of reports on different cropping pattern are available in Bangladesh and abroad (Azad et al., 1982, Soni and Kaur, 1984, Malavia et al., 1986, Khan et al., 2005, Khan et al., 2006 and Nazrul et al., 2013) but little efforts have been made for on-farm evaluation of the improved technologies of WheatJute-T.aman rice cropping pattern. The study was therefore, initiated with a view to finding out the agroeconomic feasibility of an improved package of technologies over the existing farmers' practices.

\section{Materials and Methods}

The study was conducted at Farming System Research and Development (FSRD) site of Bangladesh Agricultural Research Institute (BARI) at Hatgobindapur, Faridpur during 2011-2013. It belongs to the Low Ganges River Floodplain Agro-ecological Zone of Bangladesh (AEZ-12). The experimental site belongs to tropical monsoon climate with unimodal rainfall. The most of the rainfall was received during the months of May to September. The annual rainfall of the study period were $1548 \mathrm{~mm}$ and $1623 \mathrm{~mm}$. Mean annual minimum and maximum temperature was $21.55 / 30.96^{\circ} \mathrm{C}$ and $21.28 / 30.83^{\circ} \mathrm{C}$, respectively. 
The soil was clay loam with low organic matter content (1.24\%) and soil pH ranged from 7.0 to 8.1 neutral to slightly alkaline in nature. The statuses of $\mathrm{N}, \mathrm{P}, \mathrm{K}, \mathrm{S}, \mathrm{Zn}$ and $\mathrm{B}$ were very low, low, medium and low, respectively. (Table 1) General soil types predominantly include Calcareous Dark Grey soils and Calcareous Brown Floodplain soils. The improved cropping pattern (IP) was tested and compared against the farmers' pattern (FP) with five dispersed replications under irrigated condition. Two plots of $600 \mathrm{~m}^{2}$ were selected for each replication. One plot was under the improved pattern and the other one was farmers' pattern. In the improved pattern, BARI Gom-26 and BRRI dhan39 were introduced against BARI Gom-21 and BRRI dhan33. The jute variety JRO 524 was used in both the patterns. The agronomic practices and cultural operations for crop production under improved and farmers' practices are presented in Table 2. All field operations and management practices of both improved and farmers' patterns were closely monitored and data were recorded for agro-economic performance. The yield differences between the practices were statistically analyzed by't'-test. Agronomic performance like field duration, land use efficiency, production efficiency, sustainable yield index and rice equivalent yield of cropping patterns were calculated. Land use efficiency was worked-out by taking total duration of crops in an individual cropping pattern divided by 365 days. It was calculated by the following formula:

Land Use Efficiency $(\%)=\frac{\mathrm{d}_{1}+\mathrm{d}_{2}+\mathrm{d}_{3}}{365} \times 100$

Where $d_{1}, d_{2}$ and $d_{3}$ the duration of $1^{\text {st }}, 2^{\text {nd }}$ and $3^{\text {rd }}$ crop of the pattern

Production efficiency value in terms of $\mathrm{kgha}^{-1} \mathrm{day}^{-1}$ was calculated by total main product in a cropping pattern divided by total duration of crops in that pattern (Tomar and Tiwari, 1990).

Production Efficiency $=\frac{Y_{1}+Y_{2}+Y_{3}}{d_{1}+d_{2}+d_{3}}$

Where, $\quad Y_{1}=$ Yield of $1^{\text {st }}$ crop and $d_{1}=$ Duration of $1^{\text {st }}$ crop of the pattern

$Y_{2}=$ Yield of $2^{\text {nd }}$ crop and $d_{2}=$ Duration of $2^{\text {nd }}$ crop of the pattern

$Y_{3}=$ Yield of $3^{\text {rd }}$ crop and $d_{3}=$ Duration of $3^{\text {rd }}$ crop of the pattern

Table 1. Soil nutrient status of the experimental area (AEZ-12) of Faridpur, during 2011-2013

\begin{tabular}{|c|c|c|c|c|c|c|c|c|}
\hline \multirow[t]{2}{*}{ Parameters } & \multirow[t]{2}{*}{ OM (\%) } & \multirow[t]{2}{*}{$\mathrm{pH}$} & \multirow{2}{*}{$\begin{array}{c}\text { Total N } \\
(\%)\end{array}$} & \multirow{2}{*}{$\begin{array}{c}\mathrm{K} \\
\text { (meq/100 g } \\
\text { of soil }\end{array}$} & $\mathrm{P}$ & $\mathrm{S}$ & $\mathrm{Zn}$ & $\mathrm{B}$ \\
\hline & & & & & \multicolumn{4}{|c|}{ ( $\mu \mathrm{g} / \mathrm{g}$ soil) } \\
\hline Range & $\begin{array}{l}0.96- \\
1.52\end{array}$ & 7.0-8.1 & $0.05-0.08$ & $0.17-0.26$ & $1.90-21.00$ & $3.90-41.00$ & $0.30-1.60$ & $0.16-0.25$ \\
\hline Average & 1.24 & - & 0.063 & 0.21 & 8.25 & 22.48 & 1.00 & 0.19 \\
\hline Critical limit & - & - & 0.12 & 0.12 & 10.00 & 10.00 & 0.6 & 0.2 \\
\hline Interpretation & Low & $\begin{array}{c}\text { Neutral to } \\
\text { slightly } \\
\text { alkaline }\end{array}$ & Very low & Medium & Low & Medium & Medium & Low \\
\hline
\end{tabular}

Sustainable Yield Index (SYI): It was worked out by the following formula suggested by Krishna and Reddy (1997).

Sustainable Yield Index SYI (\%) $=\frac{Y_{\text {mean }}-S D}{Y_{\max }} \times 100$

Where, $Y_{\text {mean }}=$ Mean yield from a practice over years, $S D=$ Standard deviation of the treatment and $Y_{\max }$ $=$ Maximum yield obtained with any practice. 
Rice Equivalent Yield (REY): For comparison between crop sequences, the yield of all crops was converted into rice equivalent on the basis of prevailing market prices of individual crop (Verma and Modgal, 1983). Rice equivalent yield (REY) was computed as yield of individual crop multiplied by market price of that crop divided by market price of rice.

Rice equivalent $y$ ield $(\mathbf{t} / \mathrm{ha})=\frac{\text { Yield of individual crop } \times \text { market price of that crop }}{\text { market price of rice }}$

The economic indices like gross and net returns and benefit cost ratio were also calculated on the basis of prevailing market price of the produces.

Economic analysis involved collection of data on prices and quantities of inputs used and output produced. The inputs used included seed, fertilizer, labour and insecticides. The output and inputs were valued at market prices. The results were used to compute net income, benefit cost ratio and rice equivalent yield of crops. Net income was computed as the difference between management (Family labour and operator's) cost and gross margin. Benefit cost ratio was computed as gross return divided by total variable cost of cultivation.

Benefit Cost Ratio $(\mathrm{BCR})=\frac{\text { Gross return }}{\text { Total (variable) cost of cultivation }}$

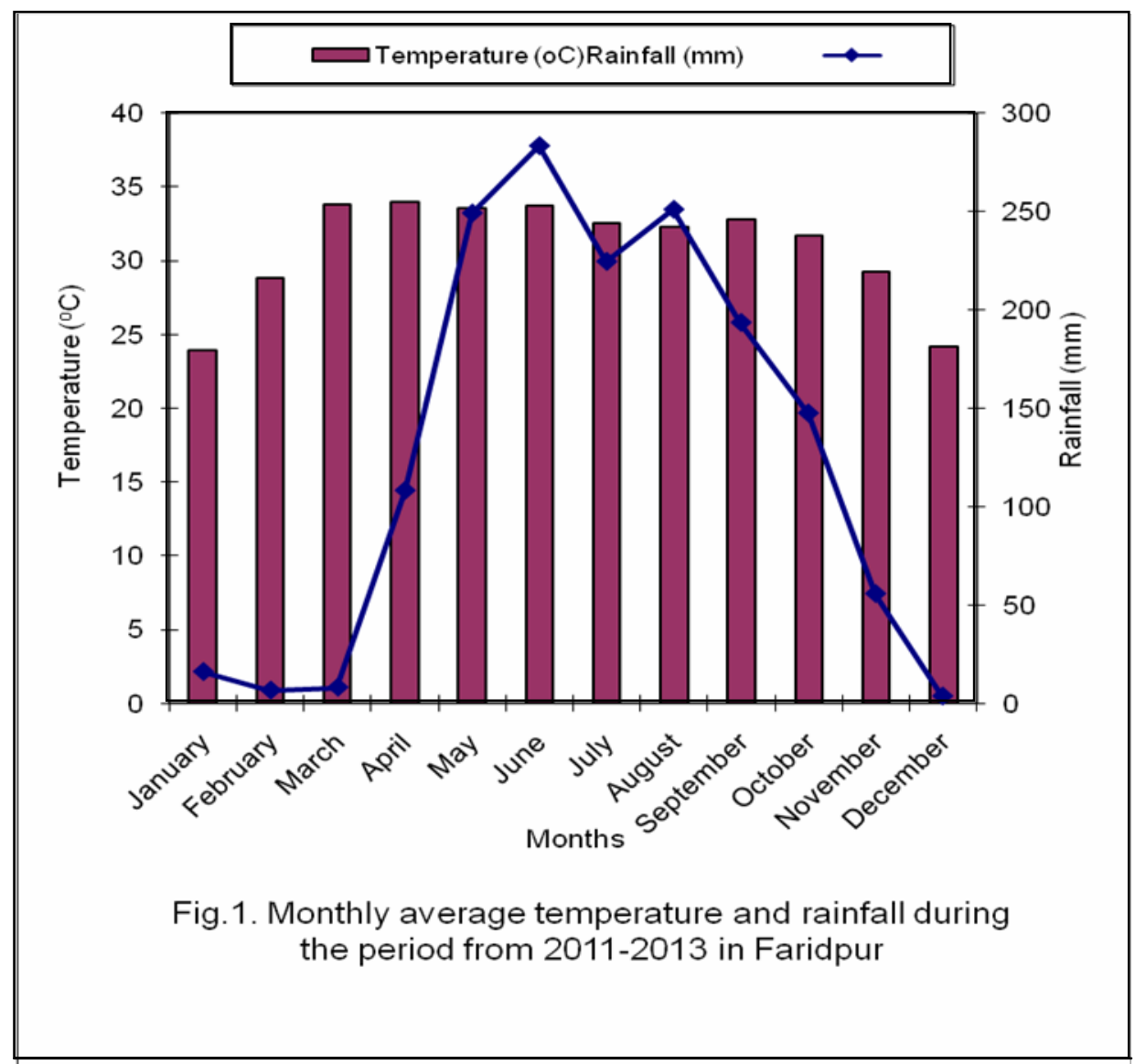




\section{Results and Discussion}

\section{Grain and Fibre Yield of the Cropping Patterns}

Results of the study have been presented in Table 3-5. It was revealed that all of the component crops of Wheat-Jute-T.aman rice cropping pattern under improved practices (IP) gave higher grain yield as well as by-product in both years (Table 3 ). On an average, the yield of wheat, jute and T.aman rice in improved pattern increased by $6.05 \%, 15.44 \%$ and $19.38 \%$, respectively over the crops of the farmers' practices (FP). The yield of improved pattern was higher due to change of variety with improved production technologies for the component crops. Similar results were also obtained by Nazrul et al. (2013), Khan et al. (2006), Khan et al. (2005) and Hossain and Wahhab (1992). In both years, farmers' pattern gave lower grain yield of wheat and fibre yield of jute due to imbalance use of fertilizers and more population. BRRI dhan39 in improved pattern performed better than BRRI dhan33 in farmers' practices due to use of balance fertilizer and modern technology.

\section{By-product Yield of the Cropping Patterns}

The improved cropping pattern produced higher by-product yield (12.73 t/ha) than the by-product yield of the crops of the farmers' pattern (11.42 t/ha). The by-product yield of improved pattern was higher due to change of variety with improved technologies for the component crops. In both years improved and farmers' pattern produced similar by-product yield of jute. But BARI Gom-26 and BRRI dhan39 performed better than BARI Gom-21 and BRRI dhan33 due to traditional farming.

\section{Field Duration}

Field duration of cropping pattern mainly depends on the individual duration of component crops. The farmers' cropping pattern Wheat-Jute-T.aman rice had the longer field duration than the improved cropping pattern Wheat-Jute-T.aman rice in both years (Table 2). In farmers' cropping pattern BARI Gom21 took longer field duration compared to BARI Gom-26 in improved pattern. As a result, production efficiency, land use efficiency and sustainable yield index were higher in improved pattern than farmers' pattern.

\section{Rice equivalent yield}

The mean rice equivalent yield revealed that improved cropping pattern produced higher rice equivalent yield over farmers' traditional cropping pattern (Table 4). Inclusion of high yielding varieties and improvement of management practices in the improved pattern increased the rice equivalent yield. Lower rice equivalent yield was obtained in the farmers' pattern due to variety and traditional management practices.

\section{Production efficiency}

Maximum production efficiency (32.80) in terms of $\mathrm{kg} / \mathrm{ha} /$ day was obtained from improved pattern in 2012-2013 closely followed by improved pattern in 2011-2012 (Table 4). The higher production efficiency of improved cropping pattern might be due to the modern varieties and management practices. The lowest production efficiency was observed in farmers' pattern due to modern management practices was absent. Mean production efficiency (32.40) in terms of $\mathrm{kg} / \mathrm{ha} /$ day was higher in improved pattern and lower (28.12) in farmers' pattern. Similar trend were noted by Nazrul et al. (2013), Khan et al. (2006), Khan et al. (2005) and Krrishna and Reddy (1997).

\section{Land use efficiency}

Land use efficiency is the effective use of land in a cropping year, which mostly depends on crop duration. Mean land use efficiency indicated that farmers' pattern used the land for $89 \%$ period of the year, whereas improved pattern used the land for $87 \%$ period of the year (Table 4 ). The higher land use efficiency in farmers' pattern because this pattern occupied the field for longest duration (324 days), whereas the improved pattern occupied the field for 319 days of the year. 
Kamrozzaman et al.

Table 2. Agronomic parameters considered in Wheat-Jute-T.aman rice cropping pattern under farmers' and improved practices at Hatgobindapur, Faridpur, during 2011-2013

\begin{tabular}{|c|c|c|c|c|c|}
\hline \multirow[t]{2}{*}{ Parameters } & \multirow{2}{*}{$\begin{array}{l}\mathrm{C}_{1}=\text { Wheat } \\
\mathrm{C}_{2}=\text { Jute } \\
\mathrm{C}_{3}=\text { T.aman }\end{array}$} & \multicolumn{2}{|c|}{ Farmers' Practice (FP) } & \multicolumn{2}{|c|}{ Improved Practice (IP) } \\
\hline & & $2011-2012$ & $2012-2013$ & 2011-2012 & $2012-2013$ \\
\hline \multirow[t]{3}{*}{ Variety } & $\mathrm{C}_{1}$ & BARI Gom-21 & BARI Gom-21 & BARI Gom-26 & BARI Gom-26 \\
\hline & $\mathrm{C}_{2}$ & JRO-524 & JRO-524 & JRO-524 & JRO-524 \\
\hline & $\mathrm{C}_{3}$ & BRRI dhan33 & BRRI dhan33 & BRRI dhan39 & BRRI dhan39 \\
\hline \multirow{3}{*}{$\begin{array}{c}\text { Sowing/ } \\
\text { transplanting time }\end{array}$} & $\mathrm{C}_{1}$ & 01-05 Dec. & 24-29 Nov. & 02-05 Dec & 24-28 Nov. \\
\hline & $\mathrm{C}_{2}$ & 08-12 April & 02-07 April & 09-12 April & 02-07 April \\
\hline & $\mathrm{C}_{3}$ & 06-12 Aug. & 7-16 Aug. & 06-12 Aug. & 07-16 Aug. \\
\hline \multirow{3}{*}{$\begin{array}{l}\text { Seed rate } \\
(\mathrm{kg} / \mathrm{ha})\end{array}$} & $\mathrm{C}_{1}$ & 120 & 120 & 120 & 120 \\
\hline & $\mathrm{C}_{2}$ & 7 & 7 & 5 & 5 \\
\hline & $\mathrm{C}_{3}$ & 50 & 50 & 40 & 40 \\
\hline \multirow{3}{*}{$\begin{array}{l}\text { Planting } \\
\text { method }\end{array}$} & $\mathrm{C}_{1}$ & Broad cast & Broad cast & Broad cast & Broad cast \\
\hline & $\mathrm{C}_{2}$ & Broad cast & Broad cast & Broad cast & Broad cast \\
\hline & $\mathrm{C}_{3}$ & Line & Line & Line & Line \\
\hline \multirow{3}{*}{$\begin{array}{c}\text { Spacing } \\
\text { (Row } \times \text { hill) }\end{array}$} & $\mathrm{C}_{1}$ & Continuous & Continuous & Continuous & Continuous \\
\hline & $\mathrm{C}_{2}$ & Continuous & Continuous & Continuous & Continuous \\
\hline & $\mathrm{C}_{3}$ & $20 \times 15$ & $20 \times 15$ & $20 \times 15$ & $20 \times 15$ \\
\hline \multirow{3}{*}{\begin{tabular}{|l} 
Seedling \\
Age (days)
\end{tabular}} & $\mathrm{C}_{1}$ & - & - & - & - \\
\hline & $\mathrm{C}_{2}$ & - & - & - & - \\
\hline & $\mathrm{C}_{3}$ & $30-40$ & $30-40$ & $30-35$ & $30-35$ \\
\hline \multirow{3}{*}{\begin{tabular}{|l} 
Seedling \\
No./hill
\end{tabular}} & $\mathrm{C}_{1}$ & - & - & - & - \\
\hline & $\mathrm{C}_{2}$ & - & - & - & - \\
\hline & $\mathrm{C}_{3}$ & $3-4$ & $3-4$ & $2-3$ & $2-3$ \\
\hline \multirow{3}{*}{$\begin{array}{c}\text { Fertilizer dose } \\
(\mathrm{kg} / \mathrm{ha}) \\
\text { NPKSZnB } \\
\end{array}$} & $\mathrm{C}_{1}$ & $45-30-40-22-3.5-2$ & $45-30-40-22-3.5-2$ & $115-35-50-20-5-1.5$ & $115-35-50-20-5-1.5$ \\
\hline & $\mathrm{C}_{2}$ & $80-10-50-0-0-0$ & $80-10-50-0-0-0$ & $148-12-46-6-0-0$ & $148-12-46-6-0-0$ \\
\hline & $\mathrm{C}_{3}$ & 73-13-25-10-0-0 & 73-13-25-10-0-0 & 86-7-14-6-1-0 & 86-7-14-6-1-0 \\
\hline \multirow[t]{3}{*}{\begin{tabular}{|c|} 
Fertilizer \\
application method
\end{tabular}} & $\mathrm{C}_{1}$ & $\begin{array}{l}\text { All fertilizer applied as } \\
\text { basal during final land } \\
\text { preparation. one-third } \\
\text { nitrogen (additional to } \\
\text { basal)under irrigated } \\
\text { condition }\end{array}$ & $\begin{array}{l}\text { All fertilizer applied } \\
\text { as basal during final } \\
\text { land preparation. } \\
\text { One-third nitrogen } \\
\text { (additional to basal) } \\
\text { under irrigated } \\
\text { condition }\end{array}$ & $\begin{array}{l}\text { Two-third of the } \\
\text { nitrogen and all other } \\
\text { fertilizers applied as } \\
\text { basal during final land } \\
\text { preparation. } \\
\text { Remaining one-third of } \\
\text { nitrogen applied at } 17- \\
21 \text { days after sowing } \\
\text { (DAS) after } 1^{\text {st }} \\
\text { irrigation }\end{array}$ & $\begin{array}{l}\text { Two-third of the } \\
\text { nitrogen and all other } \\
\text { fertilizers applied as } \\
\text { basal during final land } \\
\text { preparation. } \\
\text { Remaining one-third of } \\
\text { nitrogen applied at 17- } \\
21 \text { days after sowing } \\
\text { (DAS) after } 1^{\text {st }} \text { irrigation }\end{array}$ \\
\hline & $\mathrm{C}_{2}$ & $\begin{array}{l}\text { Half of nitrogen and all } \\
\text { other fertilizers applied } \\
\text { as basal during final } \\
\text { land preparation. } \\
\text { Remaining nitrogen } \\
\text { was top dressed at 40- } \\
45 \text { DAS under moist } \\
\text { soil condition }\end{array}$ & $\begin{array}{l}\text { Half of nitrogen and } \\
\text { all other fertilizers } \\
\text { applied as basal } \\
\text { during final land } \\
\text { preparation. } \\
\text { Remaining } \mathrm{N}_{2} \text { was } \\
\text { top dressed at 40- } \\
\text { 45 DAS under moist } \\
\text { soil condition } \\
\end{array}$ & $\begin{array}{l}\text { Half of nitrogen and all } \\
\text { other fertilizers applied } \\
\text { as basal during final } \\
\text { land preparation. } \\
\text { Remaining nitrogen } \\
\text { was top dressed at 40- } \\
45 \text { DAS under moist } \\
\text { soil condition }\end{array}$ & $\begin{array}{l}\text { Half of nitrogen and all } \\
\text { other fertilizers applied } \\
\text { as basal during final } \\
\text { land preparation. } \\
\text { Remaining nitrogen } \\
\text { was top dressed at 40- } \\
\text { 45 DAS under moist } \\
\text { soil condition }\end{array}$ \\
\hline & $\mathrm{C}_{3}$ & $\begin{array}{l}\text { All PKS used as basal } \\
\text { during final land } \\
\text { preparation. } \mathrm{N}_{2} \text { used } \\
\text { in } 2 \text { equal splits at } 15- \\
20 \text { DAT and another } \\
\text { one in 35-40 DAT. }\end{array}$ & $\begin{array}{l}\text { All PKS used as } \\
\text { basal during final } \\
\text { land preparation. } \mathrm{N}_{2} \\
\text { used in } 2 \text { equal } \\
\text { splits at } 15-20 \text { DAT } \\
\text { and another one in } \\
\text { 35-40 DAT. }\end{array}$ & $\begin{array}{l}\text { All PKSZn used as } \\
\text { basal and N used in } 3 \\
\text { equal splits, the first } \\
\text { one after 15DAT, } \\
\text { second one at 35-40 } \\
\text { DAT and third one at } \\
5-7 \text { days before } \\
\text { panicle initiation stage. } \\
\end{array}$ & $\begin{array}{l}\text { All PKSZn used as } \\
\text { basal and } \mathrm{N}_{2} \text { used in } 3 \\
\text { equal splits, the first } \\
\text { one after 15 DAT, } \\
\text { second one at 35-40 } \\
\text { DAT and third one at 5- } \\
7 \text { days before panicle } \\
\text { initiation stage. }\end{array}$ \\
\hline \multirow[t]{3}{*}{ Weeding (no.) } & $\mathrm{C}_{1}$ & 2 times & 2 times & 2 times & 2 times \\
\hline & $\mathrm{C}_{2}$ & $\begin{array}{c}2 \text { times, } 1^{\text {st }} \text { one at } 20- \\
30 \text { DAS and } 2^{\text {nd }} \text { one at } \\
50-60 \text { DAS }\end{array}$ & $\begin{array}{l}2 \text { times, } 1^{\text {st }} \text { one at } \\
20-30 \text { DAS and } 2^{\text {nd }} \\
\text { one at } 50-60 \text { DAS }\end{array}$ & $\begin{array}{l}2 \text { times, } 1^{\text {st }} \text { one at } 20- \\
25 \text { DAS and } 2^{\text {nd }} \text { one at } \\
40-45 \text { DAS }\end{array}$ & $\begin{array}{l}2 \text { times, } 1^{\text {st }} \text { one at } 20- \\
25 \text { DAS and } 2^{\text {nd }} \text { one at } \\
40-45 \text { DAS }\end{array}$ \\
\hline & $\mathrm{C}_{3}$ & $\begin{array}{c}2 \text { times weeding and } \\
\text { mulching }\end{array}$ & $\begin{array}{l}2 \text { times weeding } \\
\text { and mulching }\end{array}$ & $\begin{array}{l}2 \text { times, } 1^{\text {st }} \text { one at } 20- \\
25 \text { DAT and } 2^{\text {nd }} \text { one at } \\
40-45 \text { DAT }\end{array}$ & $\begin{array}{l}2 \text { times, } 1^{\text {st }} \text { one at } 20- \\
25 \text { DAT and } 2^{\text {nd }} \text { one at } \\
40-45 \text { DAT }\end{array}$ \\
\hline
\end{tabular}


Table 2. Contd.

\begin{tabular}{|c|c|c|c|c|c|}
\hline \multirow[t]{2}{*}{ Parameters } & \multirow{2}{*}{$\begin{array}{l}\mathrm{C}_{1}=\text { Wheat } \\
\mathrm{C}_{2}=\text { Jute } \\
\mathrm{C}_{3}=\text { T.aman }\end{array}$} & \multicolumn{2}{|c|}{ Farmers' Practice (FP) } & \multicolumn{2}{|c|}{ Improved Practice (IP) } \\
\hline & & 2011-2012 & $2012-2013$ & 2011-2012 & $2012-2013$ \\
\hline \multirow[t]{3}{*}{ Irrigation } & $\mathrm{C}_{1}$ & $\begin{array}{l}2 \text { times, } 1^{\text {st }} \text { one at } 15- \\
21 \text { DAS and } 2^{\text {nd }} \text { one at } \\
50-55 \text { DAS }\end{array}$ & $\begin{array}{l}2 \text { times, } 1^{\text {st }} \text { one at } \\
15-21 \text { DAS and } 2^{\text {nd }} \\
\text { one at } 50-55 \text { DAS }\end{array}$ & $\begin{array}{l}2 \text { times, } 1^{\text {st }} \text { one at } \\
15-21 \text { DAS and } 2^{\text {nd }} \\
\text { one at } 50-55 \text { DAS }\end{array}$ & $\begin{array}{l}2 \text { times, } 1^{\text {st }} \text { one at } 15- \\
21 \text { DAS and } 2^{\text {nd }} \text { one at } \\
50-55 \text { DAS }\end{array}$ \\
\hline & $\mathrm{C}_{2}$ & - & - & - & - \\
\hline & $\mathrm{C}_{3}$ & $\begin{array}{l}\text { One or two } \\
\text { supplemental irrigation }\end{array}$ & $\begin{array}{l}\text { One or two } \\
\text { supplemental } \\
\text { irrigation }\end{array}$ & $\begin{array}{l}\text { One or two } \\
\text { supplemental } \\
\text { irrigation }\end{array}$ & $\begin{array}{l}\text { One or two } \\
\text { supplemental irrigation }\end{array}$ \\
\hline \multirow{3}{*}{$\begin{array}{l}\text { Insect/ } \\
\text { Rodent control }\end{array}$} & $\mathrm{C}_{1}$ & Chemical & Chemical & IPM & IPM \\
\hline & $\mathrm{C}_{2}$ & - & - & IPM & IPM \\
\hline & $\mathrm{C}_{3}$ & Chemical & Chemical & IPM & IPM \\
\hline \multirow[t]{3}{*}{ Harvest time } & $\mathrm{C}_{1}$ & 29 Mar. to 04 April & 23-28 March & 26-30 March & 20-26 March \\
\hline & $\mathrm{C}_{2}$ & 01-10 August & 29-31 July & 25-31 July & 28-31 July \\
\hline & $\mathrm{C}_{3}$ & 04-12 Nov. & 03-09 Nov. & 04-14 Nov. & 05-10 Nov. \\
\hline \multirow{3}{*}{$\begin{array}{|ll|}\begin{array}{l}\text { Field } \\
\text { (days) }\end{array} & \text { duration } \\
\end{array}$} & $\mathrm{C}_{1}$ & 113 & 114 & 108 & 107 \\
\hline & $\mathrm{C}_{2}$ & 121 & 123 & 118 & 120 \\
\hline & $\mathrm{C}_{3}$ & 88 & 90 & 92 & 94 \\
\hline \multirow{3}{*}{$\begin{array}{l}\text { Grain/ Fibre } \\
\text { yield (t/ha) }\end{array}$} & $\mathrm{C}_{1}$ & 3.39 & 3.55 & 3.56 & 3.80 \\
\hline & $\mathrm{C}_{2}$ & 2.44 & 2.48 & 2.82 & 2.85 \\
\hline & $\mathrm{C}_{3}$ & 3.25 & 3.14 & 3.76 & 3.88 \\
\hline \multirow{3}{*}{\begin{tabular}{|l} 
By-product $\quad$ yield \\
(t/ha)
\end{tabular}} & $\mathrm{C}_{1}$ & 4.15 & 4.08 & 3.99 & 4.54 \\
\hline & $\mathrm{C}_{2}$ & 3.94 & 3.76 & 4.37 & 4.24 \\
\hline & $\mathrm{C}_{3}$ & 3.37 & 3.53 & 3.95 & 4.34 \\
\hline
\end{tabular}

Table 3. Productivity of Wheat-Jute-T.aman rice cropping pattern under farmers' and improved practices at Hatgobindapur, Faridpur, during 2011-2013

\begin{tabular}{|c|c|c|c|c|c|c|c|}
\hline \multirow{2}{*}{ Year } & \multirow{2}{*}{ Practice } & \multicolumn{3}{|c|}{ Grain/ Fibre yield (t/ha) } & \multicolumn{3}{c|}{ By-product yield (t/ha) } \\
\cline { 3 - 8 } & & Wheat & Jute & T.aman & Wheat & Jute & T.aman \\
\hline \multirow{2}{*}{$2011-12$} & FP & $3.19 \mathrm{~b}$ & $2.34 \mathrm{~b}$ & 3.25 & 4.15 & 3.94 & 3.37 \\
\cline { 2 - 9 } & IP & $3 . \mathrm{b} 6 \mathrm{a}$ & $2.82 \mathrm{a}$ & 3.76 & 3.99 & 4.37 & 3.95 \\
\hline \multirow{2}{*}{$2012-13$} & FP & $3.15 \mathrm{~b}$ & $2.38 \mathrm{~b}$ & $3.14 \mathrm{~b}$ & 4.08 & 3.76 & 3.53 \\
& IP & $3.80 \mathrm{a}$ & $2.85 \mathrm{a}$ & $3.88 \mathrm{a}$ & 4.54 & 4.24 & 4.34 \\
\hline \multirow{2}{*}{ Mean } & FP & $3.7 \mathrm{~b}$ & $2.36 \mathrm{~b}$ & $3.19 \mathrm{~b}$ & 4.12 & 3.85 & 3.45 \\
\cline { 2 - 9 } & IP & $3.83 \mathrm{a}$ & $2.84 \mathrm{a}$ & $3.82 \mathrm{a}$ & 4.27 & 4.31 & 4.15 \\
\hline
\end{tabular}

FP= Farmers' Practice, IP= Improved Practice, Different letter (s) with year-wise mean yield indicate significant at $5 \%$ level

\section{Sustainable yield index}

The sustainable yield index (SYI) of farmers' and improved cropping pattern are presented in Table 4. The sustainable yield index value as a measure of sustainability of the patterns which was higher in improved pattern (94\%) and lower in farmers' pattern (89\%). This indicated that improved pattern is therefore, more stable than farmers' pattern. The results are in agreement with the findings of Nazrul et al.(2013) and Khan et al. (2005).

\section{Cost benefit analysis}

From the economic point of view, the improved cropping pattern showed its superiority over farmers' pattern during two consecutive years of cropping. On an average, gross return of the improved pattern was Tk.265495/ha which was more than 9\% higher than farmers' pattern of TK. 242935/ha (Table 5). The production cost of the improved pattern (Tk. 142408/ha) was higher than farmers' pattern (Tk.138362/ha) due to labour intensive, cost of fertilizer and other inputs. The net return was substantially higher in the improved pattern (Tk.123087/ha) than farmers' pattern (Tk. 104573/ha). The higher net return of the improved pattern was achieved mainly higher yield advantages of the component crops. The $18 \%$ additional net return was achieved by adding $3 \%$ additional cost in the improved pattern. The higher cost benefit ratio further indicated the superiority of the improved pattern over the farmers' pattern. 
Table 4. Rice-equivalent yield, production efficiency, land use efficiency and sustainable yield index of farmers' and improved cropping pattern at Hatgobindapur, Faridpur during 2011-2013

\begin{tabular}{|c|c|c|c|c|c|}
\hline Year & $\begin{array}{c}\text { Cropping } \\
\text { pattern }\end{array}$ & $\begin{array}{c}\text { Rice-equivalent } \\
\text { yield (t/ha) }\end{array}$ & $\begin{array}{c}\text { Production efficiency } \\
\text { (kg/ha/day) }\end{array}$ & $\begin{array}{c}\text { Land use } \\
\text { efficiency (\%) }\end{array}$ & $\begin{array}{c}\text { Sustainable yield } \\
\text { index (\%) }\end{array}$ \\
\hline \multirow{2}{*}{$2011-12$} & FP & 13.35 & 28.20 & 88.22 & 88.24 \\
\cline { 2 - 6 } & IP & 14.97 & 31.99 & 86.85 & 92.88 \\
\hline \multirow{2}{*}{$2012-13$} & FP & 13.55 & 28.04 & 89.59 & 89.30 \\
\cline { 2 - 6 } & IP & 15.47 & 32.80 & 87.95 & 95.47 \\
\hline \multirow{2}{*}{ Mean } & FP & 13.45 & 28.12 & 88.91 & 88.78 \\
\cline { 2 - 6 } & IP & 15.22 & 32.40 & 87.40 & 94.18 \\
\hline
\end{tabular}

Table 5. Cost benefit analysis of Wheat-Jute-T.aman rice cropping pattern under farmers' and improved practices at Hatgobindapur, Faridpur, during 2011-2013

\begin{tabular}{|c|c|c|c|c|c|}
\hline Year & $\begin{array}{c}\text { Cropping } \\
\text { pattern }\end{array}$ & $\begin{array}{c}\text { Gross return } \\
\text { (Tk/ha) }\end{array}$ & $\begin{array}{c}\text { Cost of cultivation } \\
\text { (Tk/ha) }\end{array}$ & $\begin{array}{c}\text { Net return } \\
\text { (Tk/ha) }\end{array}$ & BCR \\
\hline \multirow{2}{*}{$2011-12$} & FP & 234590 & 133240 & 101350 & 1.76 \\
\cline { 2 - 6 } & IP & 259950 & 138285 & 121665 & 1.88 \\
\hline \multirow{2}{*}{$2012-13$} & FP & 251280 & 143484 & 107796 & 1.75 \\
\cline { 2 - 6 } & IP & 271040 & 146532 & 124508 & 1.85 \\
\hline \multirow{2}{*}{ Mean } & FP & 242935 & 138362 & 104573 & 1.76 \\
\cline { 2 - 6 } & IP & 265495 & 142408 & 123087 & 1.86 \\
\hline
\end{tabular}

\section{Conclusion}

Considering higher rice-equivalent yield, net monetary return and more sustainability of the improved cropping pattern (Wheat-Jute-T.aman) with modern variety BARI Gom-26 and BRRI djan39 with improved technologies could be suggested for medium high land of the Low Ganges River Floodplain Agroecological Zone (AEZ-12) of Bangladesh

\section{Acknowledgement}

Authors are gratefully acknowledged On-Farm Research Division, Bangladesh Agricultural Research Institute, Gazipur and Meteorological Department, Faridpur for providing financial help and logistic support and weather data, respectively.

\section{References}

Alam, Q.M., Nazrul Islam, M., Haque, A.K.M.H. and Kundu, T.K. 1998. Economic Profitability of growing mustard/potato as an additional crop between two rice crops in Bogra district of Bangladesh. Bangladesh J. Agril. Res. 23 (4):717-730.

Azad, A.K., Talukder, F.A.H., Wahhab, M.A. and Khan, M.A. 1982. Progress and prospect of jute based cropping systems research in Bangladesh. Proc. Expert Cons. Jute and Kenaf Improvement: pp. 244-267.

BBS. 2012. Statistical Year Book of Bangladesh. Bangladesh Bureau of Statistics, planning Division, Ministry of Planning. Government of the Peoples Republic of Bangladesh

Hossain, M.A. and Wahhab, M.A. 1992. Demonstration-cum-assessment of recommended and farmers technologies in jute cultivation. Abs. of Research. Agril. Res. On Jute, Bangladesh Jute Research Institute. P. 250.

Khan, M.A.H., Quayyum, M.A., Nazrul, M.I., Sultana, N. and Mollah, M.R.A. 2005. On-Farm evaluation of production potential and economics mustard-rice based improved cropping system. Bangladesh J. Socio. Res. Dev. 2 (1): 37-42.

Khan, M.A., Hossain, S.M.A. and Khan, M.A.H. 2006. A study on some selected jute based cropping patterns at Kishoregonj. Bangladesh J. Agril. Res. 31 (1): 85-95.

Krishna, A. and Anand Reddy, K. 1997. Production potential and economics of different rice (Oryza sativa) based cropping systems in Andhra Pradesh. Indian J. Agril. Sci. 67 (12):551-553. 
Malavia, D.D., Singh, M.P., Vyas, M.N., Patel, J.C. and Kalaria, K.K. 1986. Production potential and economic feasibility of different crop sequences. Indian J. Agron. 31 (1): 75-78.

Nazrul, M.I., Shaheb, M.R., Khan, M.A.H. and Khan, A.S.M.M.R. 2013. On-Farm evaluation of production potential and economic returns of potato-rice based improved cropping system. Bangladesh Agron. J. 16 (2): 41-50.

Soni, P.N. and Rajinder Kaur. 1984. Studies on production potential of different cropping systems. Indian J. Agron. 29 (3): $367-378$.

Tomer, S.S. and Tiwari, A.S. 1990. Production potential and economics of different crop sequences. Indian J. Agron. 35 (1\&2): 30-35.

Verma, S.P. and Modgal, S.C. 1983. Production potential and economics of fertilizer application as resources constraints in maize, wheat crop sequence. Himachal J. Agric. Res. 9 (2):89-92. 